\title{
Complex genetic population structure of the bivalve Cerastoderma glaucum in a highly fragmented lagoon habitat
}

\author{
K. Tarnowska ${ }^{1,2}$, A. Chenuil ${ }^{2, *}$, R. Nikula ${ }^{3,4}$, J.-P. Féral ${ }^{2}$, M. Wołowicz ${ }^{1}$ \\ ${ }^{1}$ Laboratory of Estuarine Ecology, Institute of Oceanography, University of Gdań sk, Al. Piłsudskiego 46, 81-378 Gdynia, Poland \\ ${ }^{2}$ UMR 6540 CNRS DIMAR, Centre d'Océanologie de Marseille, Université de la Méditerranée, Station Marine d'Endoume, \\ Rue de la Batterie des Lions, 13007 Marseille, France \\ ${ }^{3}$ Finnish Museum of Natural History, PO Box 26, 00014 University of Helsinki, Finland \\ ${ }^{4}$ Department of Zoology, University of Otago, PO Box 56, Dunedin 9054, New Zealand
}

\begin{abstract}
The genetic structure of a lagoon specialist, the bivalve Cerastoderma glaucum, was studied from 4 nuclear microsatellite loci and sequences from a 514 bp mitochondrial DNA region. Both marker types revealed strong differentiation among populations that is likely due to the highly fragmented distribution of this species. The geographic location and strength of the major divisions were different between the genomes. The deepest phylogeographic split in mtDNA grouped Aegean Sea and Ponto-Caspian region populations against the more western populations, whereas nuclear data singled out Ionian Sea populations or indicated a Ponto-Caspian character of nuclear DNA from the Ionian Sea. In agreement with their presumably rapid post-glacial establishment, the northern populations showed evidence of founder effects and strong genetic drift in their genetic structuring. Two unexpected geographic disjunctions were detected in the mtDNA, but not in the microsatellite characteristics, of the studied populations. We suspect long-distance dispersal via migrating birds to be a probable dispersal means among isolated lagoon habitats and to have generated the disjunctions by contributing to the post-glacial spread of C. glaucum to its northern distribution area. The discrepancies between the nuclear and mitochondrial genetic characteristics of the populations could be a result of selective sweeps in mtDNA, sex-biased dispersal, biased effective sex ratio or differential introgression of the genomes. The high level of differentiation found between the main genetic groups led us to conclude that the taxonomy of Cerastoderma needs revision, but we acknowledge that due to hybridization the taxa can be occasionally impossible to delineate.
\end{abstract}

KEY WORDS: Microsatellites $\cdot$ mtDNA $\cdot$ Lagoon $\cdot$ Glacial refuge

\section{INTRODUCTION}

Lagoons are extreme, fragile and highly unpredictable habitats. Although many lagoon specialist invertebrates have planktonic larvae, the level of gene flow among populations is not necessarily proportional to geographic distances among them, as human activity or transport via birds may provoke migration between isolated lagoons (Barnes 1988). Due to extreme shortterm variations in physical conditions, genotypes which are adapted to a wide range of environmental conditions are favoured in lagoons (Lynch 1984). Pop- ulations of lagoon specialists are subject to marked temporal variation in population size, leading to frequent bottlenecks and founder events after local extinctions (e.g. Mason 1986).

Large-scale genetic structures of lagoon species are influenced not only by contemporary barriers to gene flow, but also by historical conditions, like Pleistocene glaciations (e.g. Pannacciulli et al. 1997, Luttikhuizen et al. 2003). Many marine ecosystems in northern parts of Europe are young, i.e. established post-glacially (Dawson 1992). During glaciations, the Mediterranean Sea and southern Atlantic coasts of Europe were potential 
refugia for coastal species whose northern distribution areas were rendered uninhabitable (reviewed in Patarnello et al. 2007, Maggs et al. 2008).

The lagoon cockle Cerastoderma glaucum (Lamellibranchia: Cardiidae) is a euryhaline and eurythermic (Rygg 1970) bivalve present across Europe from the Caspian to the Baltic Seas (Brock 1979). It is a lagoon specialist with a fragmented distribution area, as it cannot survive in loose-sediment habitats exposed to currents and waves (Brock 1979). Any autonomous long-distance dispersal of this gonochoric species is restricted to the $1 \mathrm{wk}$ pelagic larval stage (Barnes 1980).

We investigated the population genetic structure of Cerastoderma glaucum in order to (1) explore the influence of a highly fragmented lagoon habitat and (2) compare the genetic patterns in northern, postglacially colonized regions of Europe and in southern regions, where the species has a longer uninterrupted history. We used newly available nuclear (microsatellite) markers and mitochondrial DNA, and included previously unsampled regions (Hummel et al. 1994, Mariani et al. 2002, Nikula \& Väinölä 2003).

\section{MATERIALS AND METHODS}

Sampling and DNA extraction. Samples of Cerastoderma glaucum were collected from 20 locations (Fig. 1). They were stored in $95 \%$ ethanol before analysis. DNA was extracted from about $1 \mathrm{~mm}^{3}$ foot tissue using the QIAamp DNA Mini Kit (Qiagen).

Amplification and sequencing of the cytochrome c oxidase subunit I (COI) locus. A fragment of $580 \mathrm{bp}$ was amplified with species-specific primers (F: 5'-CTA YCT AGC TTT TTG AGC GGG-3'; R: 5'-CAC CWC CCC CAA CTG GAT CGA-3') designed based on $657 \mathrm{bp}$ sequences obtained with universal primers (Folmer et al. 1994). PCR was performed in a Bio-Rad DNA Engine Gradient Cycler. It started with 4 min at $94^{\circ} \mathrm{C}$ followed by 35 cycles at $94^{\circ} \mathrm{C}$ for $30 \mathrm{~s}, 65^{\circ} \mathrm{C}$ for $30 \mathrm{~s}$ and $72^{\circ} \mathrm{C}$ for $1 \mathrm{~min}$. Each PCR mixture (volume $25 \mu \mathrm{l})$ contained $1.5 \mu \mathrm{l}$ of DNA extract, $1 \mu \mathrm{M}$ of each primer, $265 \mu \mathrm{M}$ dNTPs, $1 \times$ PCR buffer, $2.5 \mathrm{mM} \mathrm{MgCl}_{2}$ and 0.65 units of GoTaq Flexi DNA Polymerase (Promega). Amplification results were verified by $2 \%$ TAE agarose gel electrophoresis. PCR products from 311 cockles were sequenced in the forward direction at the

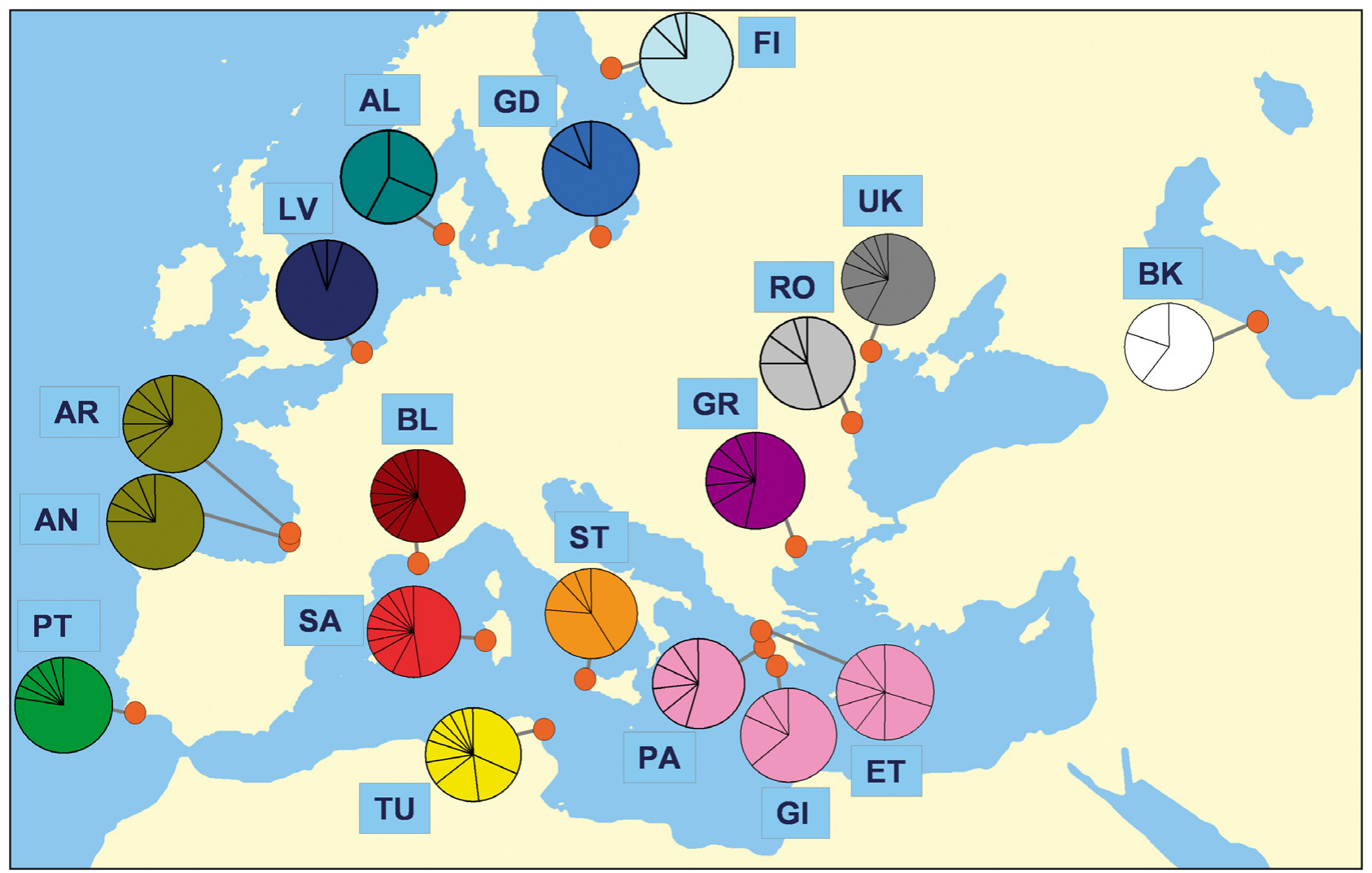

Fig. 1. Cerastoderma glaucum. Sampling locations and cytochrome c oxidase subunit I haplotypes in each population (see Table 3 for site definitions). Distinct haplotypes found in a sample population are marked by pie slices. Colours depict the separate populations or groups of closely-related populations. The variable nucleotide positions and the frequency of each haplotype are given in Fig. S1 and Table S1 in the supplement at www.int-res.com/articles/suppl/m406p173_app.pdf 
Sequencing Platform GENOMER in Roscoff (France). Sequences of all found haplotypes were deposited in GenBank (FJ555376-FJ555465).

Amplification and genotyping of microsatellite loci. Nuclear DNA was amplified using 4 pairs of microsatellite primers isolated and characterized by Pearson (2003). Repeat fragments were: (GT) for loci $\mathrm{Cg} 4$ and Cg7, (GACA) for $C g 9$ and (C) and (CA) for $C g 11$. PCR conditions were: $2 \mathrm{~min}$ at $94^{\circ} \mathrm{C}$ followed by 25 cycles (30 cycles in the case of $\mathrm{Cg} 9$ ) of denaturation for $30 \mathrm{~s}$ at $94^{\circ} \mathrm{C}$, annealing for $30 \mathrm{~s}$ at $45^{\circ} \mathrm{C}(\mathrm{Cg} 9), 50^{\circ} \mathrm{C}(\mathrm{Cg} 4$ and $\mathrm{Cg} 11)$ or $55^{\circ} \mathrm{C}\left(\mathrm{Cg}^{7}\right)$ and elongation for $1 \mathrm{~min}$ at $72^{\circ} \mathrm{C}$. A 20 min step at $72^{\circ} \mathrm{C}$ ended the reaction. PCR mixture (volume $10 \mu \mathrm{l}$ ) contained $0.7 \mu \mathrm{l}$ of DNA extract, $1.675 \mathrm{mM}$ ( $\mathrm{Cg} 4$ and $\mathrm{Cg} 7$ ) or $2 \mathrm{mM}$ ( $\mathrm{Cg} 9$ and $\mathrm{Cg} 11)$ of $\mathrm{MgCl}_{2}, 0.25$ units of GoTaq Flexi DNA Polymerase and other reaction chemicals in the same concentrations as for COI. The forward primers were fluorescently labelled. Microsatellite alleles were visualized on the ABI 3130 automated sequencer using multiplex electrophoresis. Most PCR products were diluted 10 times before visualization. Each well contained $10 \mu \mathrm{l}$ of deionizer formamid (HI-DI, Applied Biosystems), $0.2 \mu \mathrm{l}$ of size standard (Gene Scan 600-Liz, Applied Biosystems) and $8 \mu \mathrm{l}$ of PCR products ( $2 \mu \mathrm{l}$ of each of the amplified loci per individual). In each 96 well plate, 5 to $10 \%$ of individuals had been genotyped on previous runs to allow cross-comparisons. After excluding individuals which did not amplify at any locus, the analyses were performed on genotypes from 500 individuals.

COI data analysis. COI sequences were aligned using BIOEDIT (Hall 1999). A fragment of 514 bp was chosen for further analysis. Sequences from Sicily (SE, SM and SS) were pooled together and referred to as ST because of problems with amplification of mtDNA COI in these populations and the geographic proximity of the samples. The phylogenetic network of COI haplotypes based on the median-joining vectors method was generated with NETWORK v.4.5 (Bandelt et al. 1999). The average uncorrected percentage difference between the 2 main haplotype groups was calculated and the amino acid translation of the sequences was performed using MEGA 4 (Tamura et al. 2007). The number of segregating sites $(S)$, haplotype diversity $\left(H_{\mathrm{D}}\right.$; Nei 1987) and nucleotide diversity $(\pi ;$ Nei 1987$)$ were computed in DnaSP v.4.10.9 (Rozas et al. 2003), as well as the neutrality statistics of Tajima (1989) (D) and Fu \& Li (1993) $\left(D^{*}, F^{*}\right)$. Pairwise $F_{\mathrm{ST}}$ values between populations (Weir \& Hill 2002) were computed using ARLEQUIN v.3.1 (Excoffier et al. 2005) and they were scaled multidimensionally (MDS; XLstat 7.5.2) in order to visualize similarities among populations without assuming tree-like relationships.

Analysis of microsatellite data. Observed and expected heterozygosities $\left(H_{\mathrm{OBS}}\right.$ and $H_{\mathrm{NB}}$ without bias; Nei
1978), mean reduction in heterozygosity ( $F_{\mathrm{ISi}}$ Weir \& Cockerham 1984) within each population and linkage disequilibria ( $D$; Weir 1979) between pairs of microsatellite loci were estimated using GENETIX v.4.02 (Belkhir et al. 1998). Significance $(\alpha=0.05)$ was tested with 1000 permutations (of alleles for $F_{\mathrm{IS}}$, and of single locus genotypes within each population for $D$ ). The number of private alleles per population and per locus was counted. Robust Multilocus Estimation of Selfing (RMES) software (David et al. 2007) was applied to reveal biparental inbreeding in the populations. Selfing rate $(s)$, interpreted as inbreeding rate in gonochoric species, was deduced from an estimator of the 2-locus heterozygosity disequilibrium over all pairs of loci $\left(\hat{g}_{2}\right)$ under the assumption of inbreeding and linkage equilibrium. P-values for the null hypothesis $s=\hat{g}_{2}=0$ were obtained by resampling single-locus genotypes independently 1000 times $(\alpha=0.05)$. The level of significance was corrected using the method of Benjamini \& Hochberg (1995) for multiple statistical tests (Verhoeven et al. 2005).

Pairwise $F_{\mathrm{ST}}$ values between populations for each locus separately and over all loci were calculated according to Weir \& Cockerham (1984) using GENETIX v.4.02. The significance levels $(\alpha=0.05)$ obtained from 1000 permutations were corrected as above. Selection signals were screened from various subsets of populations with the $F_{\mathrm{ST}}$ outlier approach implemented in LOSITAN (Beaumont \& Nichols 1996, Antao et al. 2008) under the stepwise mutation model with 10000 simulations. This method evaluates the relationship between $F_{\mathrm{ST}}$ and expected heterozygosity $\left(H_{\mathrm{EXP}}\right)$ under an island model of migration. It is based on the assmption that the expected amount of inbreeding experienced at different loci should be the same because of the shared demographic history experienced at those loci. Selection, by contrast, can alter the apparent degree of inbreeding at individual loci (Lewontin \& Krakauer 1973).

An individual-based Bayesian analysis was performed for the microsatellite multilocus data using STRUCTURE software (Pritchard et al. 2000). No a priori information of the geographic origin of individuals was given. Posterior probability of the data was estimated for 1 to 20 genetic clusters $(K)$, with 12 iterations for each $K$-value, under the admixture and correlated allele frequencies models. The burn-in length was set at 50000 and the run length was 250000 Markov chain repetitions. The most probable number of clusters was estimated based on the second order rate of change in the $\log$ probability of the data $(\log K)$ between successive values of $K$ (Evanno et al. 2005). The outputs of the replicate runs with the same $K$ value were combined using CLUMPP v.1.1.1 (Jakobsson \& Rosenberg 2007), with the 'greedy' algorithm, $G$ ' pairwise matrix similarity statistic and 1000 random input orders. DISTRUCT v.1.1 (Rosenberg 2004) was used to display the results. 


\section{RESULTS}

\section{Variability among populations}

We found 90 mtDNA haplotypes and 92 variable sites (Fig. S1 \& Table S1 in the supplement at www.int-res. com/articles/suppl/m406p173_app.pdf). The COI haplotype network opposed 2 main phylogroups with a $6.6 \%$ of average uncorrected sequence divergence: an eastern Haplogroup VI joining the populations from the Aegean Sea (GR) and the Ponto-Caspian region (UK, $\mathrm{RO}$ and BK) against more westerly samples (Haplogroups I to V; Fig. 2).

The divergences of haplotypes within Haplogroups I to III were much smaller than divergences of haplotypes within Haplogroups IV (Tunisia) and V (Ionian Sea) (Fig. 2).

Within the western phylogroup, 2 striking geographic disjunctions were detected: haplotypes in the Baltic Sea (FI and GD) were similar to the Portuguese (PT) haplotypes (Haplogroup I), and haplotypes from Sardinia (SA) and 2 haplotypes from the Berre Lagoon (BL) resembled those from the Atlantic coast of France (AN and AR) and the North Sea (LV and AL) (Haplogroup II) (Fig. 2). Even though these geographically distant populations belonged to the same haplogroups, they did not share iden- tical haplotypes. Population pairwise $F_{\mathrm{ST}}$ values for COI sequences (Fig. 3a, Table 1) revealed strong geographic structuring.

The total number of alleles at each microsatellite locus was 42 for $C g 4,25$ for $C g 7,63$ for $C g 9$ and 24 for $C g 11$ (Table $\mathrm{S} 2$ in the supplement). No linkage disequilibrium was detected between loci. Microsatellites revealed a main division between the Ionian Sea and all the other regions (Fig. 3b, Table 1). This division was mostly supported by locus $C g 11$ where the Ionian Sea populations exhibited very low genetic diversity (non-biased heterozygosity) and high pairwise populations $F_{\mathrm{ST}}$ when compared to other loci (Tables S3 \& S4 in the supplement). Positive selection was inferred to affect this locus in the Ionian Sea $(p=0.016)$. Population pairwise $F_{\mathrm{ST}}$ values computed omitting $C g 11$ showed that the nuclear genome of the Ionian Sea populations was most similar to the Ponto-Caspian populations (Fig. 3c). A strong genetic structure was revealed with microsatellites (Fig. $3 \mathrm{~b}, \mathrm{c}$, Table 1) and $F_{\mathrm{ST}}$ values were higher between northern than southern populations. Differentiation among populations was mostly the result of differences in allele frequencies, not of private alleles (Table 2). Four panmictic units, each forming geographically continuous areas, were inferred by STRUCTURE (Fig. 4). Baltic Sea and North Sea populations were fairly similar in compo-

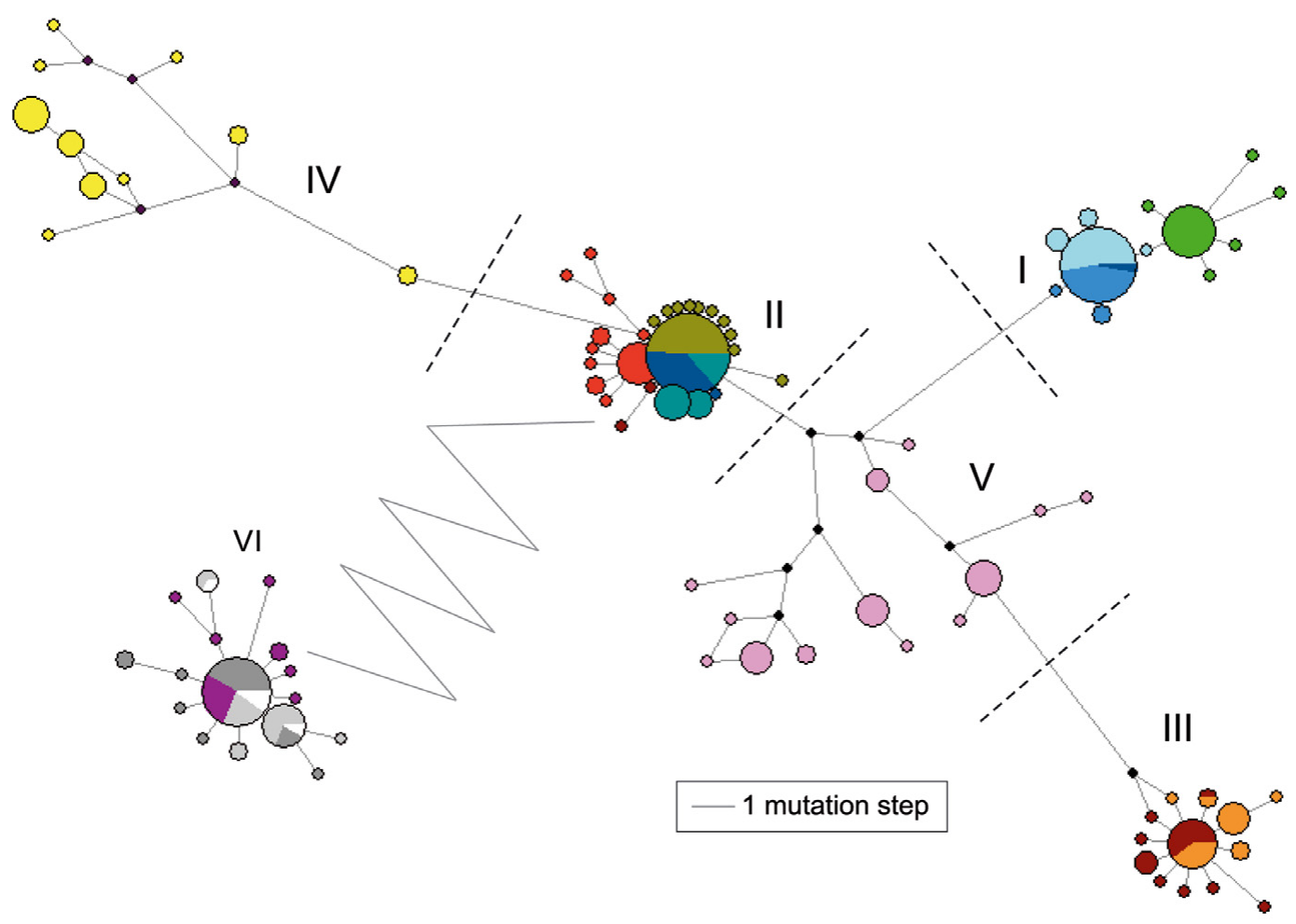

Fig. 2. Cerastoderma glaucum. Cytochrome c oxidase subunit I (COI) haplotype networks. Circle sizes are proportional to the frequency of the haplotypes and the colours correspond to those in Fig. 1. Haplogroups are arbitrarily numbered from I to VI to facilitate description. The length of the line connecting haplotypes (from centre to centre) reflects the number of inferred mutations separating them (see scale bar). The zig-zag line reflects the number of nucleotide differences (26) between the 2 most similar haplotypes from the 2 main mtDNA lineages of C. glaucum 

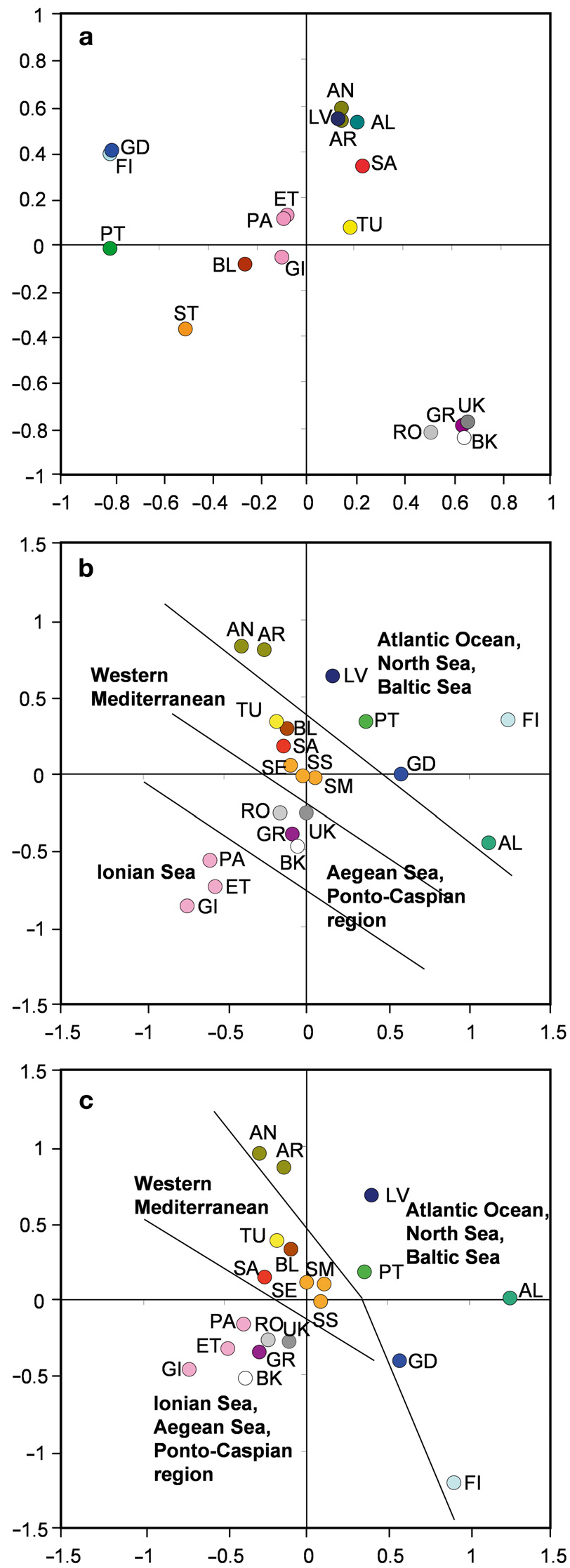

sition, and the Bay of Biscay populations most resembled the Portuguese population, although their mtDNA belonged to different haplogroups. Omitting the putatively selection-affected locus $C g 11$ did not change the pattern of STRUCTURE inferences. Admixture of the inferred units appeared most extensive in the western Mediterranean individuals.

\section{Variability within populations}

Mediterranean populations exhibited higher haplotype and nucleotide diversity than North Sea and Baltic Sea populations (Table 3). The neutrality tests yielded significant results for 3 Atlantic coast populations (AR, AN and PT) and for 1 North Sea population (LV).

Based on the $F_{\text {IS }}$ values estimated from the microsatellite data, 11 populations exhibited significant departures from Hardy-Weinberg equilibrium ( $F_{\text {IS }}$ values for each locus; Table S5 in the supplement). RMES analyses suggested that in 5 of these populations (SE, SM, TU, RO and UK) the reason for the disequilibrium (heterozygote deficiency) was biological (i.e. affecting all loci similarly), not merely artefactual such as the presence of null alleles (Table 2).

\section{DISCUSSION}

\section{Heterozygote deficiency in Cerastoderma glaucum populations}

Biological causes of heterozygote deficiency include (1) inbreeding, causing high proportion of homozygotes across all loci; $(2)$ the Wahlund effect, i.e. the union of 2 or more populations genetically differentiated in the sample (Castric et al. 2002); and (3) selection against heterozygotes. The heterozygote deficiency affecting all loci similarly was detected with RMES software in 5 populations (SE, SM, TU, RO and UK). The STRUCTURE analyses suggested that Mediterranean Sea populations (SE, SM and TU) were composed of a mixture of genotypes of different origins (Fig. 4), indicating a possible Wahlund effect, but the pattern found in the Mediterranean Sea might have been due to other reasons, like the high number of missing data in the sam-

Fig. 3. Cerastoderma glaucum. Non-metric multidimensional scaling of population pairwise $F_{\mathrm{ST}}$ values. Populations are marked with the same colours as in Fig. 1. Solid diagonal lines show divisions into geographical regions (see Table 3 for site definitions). (a) mtDNA data (stress $=0.122$ ), (b) microsatellite data (stress $=0.126$ ), (c) microsatellite data, locus Cg11 excluded (stress $=0.120$ ) 
Table 1. Cerastoderma glaucum. Upper triangular matrix: population pairwise $F_{\mathrm{ST}}$ values based on mtDNA sequence data (SE, SM and SS population data were pooled ['ST']). Lower triangular matrix: multilocus population pairwise $F_{\mathrm{ST}}$ values based on microsatellite data. Non-significant values are in italics. -: no comparison made at this population level; see Table 3 for site definitions

\begin{tabular}{|c|c|c|c|c|c|c|c|c|c|c|c|c|c|c|c|c|c|c|c|c|}
\hline & FI & GD & $\mathrm{AL}$ & LV & $\mathrm{AR}$ & AN & $\mathrm{PT}$ & BL & SA & TU & ST/SE & $\mathrm{SM}$ & SS & GI & ET & PA & GR & $\mathrm{RO}$ & UK & BK \\
\hline FI & & 0.05 & 0.93 & 0.91 & 0.93 & 0.94 & 0.78 & 0.83 & 0.89 & 0.86 & 0.93 & - & - & 0.88 & 0.79 & 0.81 & 0.98 & 0.97 & 0.98 & 0.98 \\
\hline GD & 0.09 & & 0.93 & 0.92 & 0.93 & 0.95 & 0.80 & 0.82 & 0.89 & 0.85 & 0.93 & - & - & 0.87 & 0.77 & 0.79 & 0.98 & 0.97 & 0.98 & 0.98 \\
\hline $\mathrm{AL}$ & 0.24 & 0.15 & & 0.19 & 0.20 & 0.23 & 0.92 & 0.79 & 0.40 & 0.73 & 0.91 & - & - & 0.83 & 0.70 & 0.72 & 0.97 & 0.97 & 0.97 & 0.97 \\
\hline LV & 0.19 & 0.13 & 0.19 & & -0.01 & -0.01 & 0.90 & 0.78 & 0.33 & 0.72 & 0.90 & - & - & 0.81 & 0.68 & 0.70 & 0.97 & 0.97 & 0.97 & 0.97 \\
\hline $\mathrm{AR}$ & 0.27 & 0.18 & 0.29 & 0.11 & & 0.01 & 0.92 & 0.78 & 0.34 & 0.71 & 0.90 & - & - & 0.82 & 0.68 & 0.70 & 0.97 & 0.97 & 0.97 & 0.97 \\
\hline AN & 0.32 & 0.21 & 0.31 & 0.11 & 0.01 & & 0.93 & 0.80 & 0.36 & 0.72 & 0.92 & - & - & 0.84 & 0.70 & 0.72 & 0.97 & 0.97 & 0.97 & 0.98 \\
\hline $\mathrm{PT}$ & 0.20 & 0.08 & 0.21 & 0.14 & 0.13 & 0.15 & & 0.82 & 0.88 & 0.85 & 0.92 & - & - & 0.86 & 0.78 & 0.80 & 0.97 & 0.97 & 0.97 & 0.98 \\
\hline BL & 0.25 & 0.14 & 0.20 & 0.11 & 0.10 & 0.12 & 0.10 & & 0.77 & 0.74 & 0.09 & - & - & 0.67 & 0.61 & 0.66 & 0.94 & 0.94 & 0.94 & 0.92 \\
\hline SA & 0.24 & 0.14 & 0.20 & 0.12 & 0.09 & 0.10 & 0.11 & 0.03 & & 0.70 & 0.87 & - & - & 0.79 & 0.67 & 0.69 & 0.95 & 0.95 & 0.96 & 0.95 \\
\hline TU & 0.25 & 0.15 & 0.23 & 0.10 & 0.07 & 0.08 & 0.10 & 0.02 & 0.01 & & 0.80 & - & - & 0.76 & 0.69 & 0.70 & 0.92 & 0.92 & 0.93 & 0.90 \\
\hline SE/ST & 0.21 & 0.10 & 0.19 & 0.09 & 0.12 & 0.14 & 0.07 & 0.05 & 0.04 & 0.05 & & - & - & 0.80 & 0.73 & 0.77 & 0.97 & 0.97 & 0.97 & 0.97 \\
\hline SM & 0.24 & 0.10 & 0.15 & 0.08 & 0.15 & 0.16 & 0.08 & 0.06 & 0.06 & 0.07 & 0.00 & & - & - & - & - & - & - & - & - \\
\hline SS & 0.18 & 0.07 & 0.17 & 0.11 & 0.13 & 0.16 & 0.08 & 0.06 & 0.04 & 0.06 & 0.00 & 0.01 & & - & - & - & - & - & - & - \\
\hline GI & 0.36 & 0.25 & 0.36 & 0.27 & 0.31 & 0.33 & 0.29 & 0.22 & 0.21 & 0.24 & 0.17 & 0.16 & 0.16 & & 0.35 & 0.47 & 0.95 & 0.96 & 0.96 & 0.94 \\
\hline ET & 0.32 & 0.21 & 0.32 & 0.23 & 0.29 & 0.30 & 0.25 & 0.19 & 0.19 & 0.21 & 0.13 & 0.12 & 0.12 & 0.04 & & 0.08 & 0.92 & 0.93 & 0.93 & 0.89 \\
\hline PA & 0.31 & 0.19 & 0.32 & 0.20 & 0.24 & 0.26 & 0.23 & 0.17 & 0.16 & 0.18 & 0.10 & 0.10 & 0.10 & 0.03 & 0.01 & & 0.92 & 0.93 & 0.93 & 0.90 \\
\hline GR & 0.21 & 0.13 & 0.23 & 0.18 & 0.18 & 0.19 & 0.14 & 0.12 & 0.07 & 0.11 & 0.08 & 0.10 & 0.08 & 0.14 & 0.12 & 0.11 & & 0.17 & 0.06 & -0.03 \\
\hline RO & 0.24 & 0.13 & 0.20 & 0.14 & 0.17 & 0.16 & 0.15 & 0.10 & 0.05 & 0.10 & 0.06 & 0.07 & 0.06 & 0.14 & 0.11 & 0.10 & 0.02 & & 0.09 & -0.02 \\
\hline UK & 0.21 & 0.09 & 0.18 & 0.13 & 0.16 & 0.16 & 0.12 & 0.11 & 0.07 & 0.10 & 0.07 & 0.06 & 0.06 & 0.16 & 0.12 & 0.11 & 0.03 & 0.00 & & -0.02 \\
\hline BK & 0.30 & 0.16 & 0.22 & 0.22 & 0.23 & 0.22 & 0.16 & 0.12 & 0.07 & 0.13 & 0.09 & 0.08 & 0.08 & 0.16 & 0.12 & 0.13 & 0.02 & 0.00 & 0.02 & \\
\hline
\end{tabular}

Table 2. Cerastoderma glaucum. Genetic diversity in microsatellites. N: number of individuals; $H_{\mathrm{NB}}$ : expected heterozygosity without bias; $H_{\mathrm{OBS}}$ : observed heterozygosity; private alleles: number of private alleles at each locus; $F_{\text {IS }}$ : mean reduction in heterozygosity within a population (significant $F_{\mathrm{IS}}$ in bold); $\hat{g}_{2}$ : estimator of the 2-locus heterozygosity disequilibrium over all pairs of loci; $s\left(\hat{g}_{2}\right)$ : selfing rate, in this case inbreeding rate. See Table 3 for site definitions

\begin{tabular}{|c|c|c|c|c|c|c|c|c|}
\hline Site & $\mathrm{N}$ & $H_{\mathrm{NB}}$ & $H_{\mathrm{OBS}}$ & $\begin{array}{l}\text { Mean no. } \\
\text { alleles locus }^{-1}\end{array}$ & $\begin{array}{l}\text { Private alleles } \\
\text { Cg4/Cg7/ } \\
\text { Cg9/Cg11 }\end{array}$ & $F_{\mathrm{IS}}$ & $\hat{g}_{2}$ & $s\left(\hat{g}_{2}\right)$ \\
\hline FI & 29 & 0.56 & 0.54 & 6.25 & $1 / 1 / 0 / 1$ & 0.03 & 0.07 & 0.20 \\
\hline GD & 30 & 0.71 & 0.57 & 10.25 & $5 / 0 / 1 / 0$ & 0.20 & -0.05 & 0.00 \\
\hline AL & 28 & 0.58 & 0.57 & 5.25 & 0/0/0/0 & 0.02 & -0.06 & 0.00 \\
\hline LV & 30 & 0.65 & 0.70 & 5.50 & $0 / 0 / 0 / 0$ & -0.09 & 0.09 & 0.25 \\
\hline AR & 24 & 0.65 & 0.63 & 7.50 & $1 / 0 / 0 / 0$ & 0.03 & 0.00 & 0.03 \\
\hline AN & 24 & 0.63 & 0.60 & 7.50 & $0 / 0 / 0 / 0$ & 0.05 & 0.04 & 0.14 \\
\hline PT & 29 & 0.72 & 0.53 & 7.25 & $0 / 0 / 0 / 0$ & 0.26 & 0.22 & 0.44 \\
\hline BL & 29 & 0.75 & 0.72 & 10.75 & 0/0/0/1 & 0.04 & -0.03 & 0.00 \\
\hline SA & 23 & 0.80 & 0.68 & 10.25 & $2 / 0 / 2 / 1$ & 0.15 & -0.07 & 0.00 \\
\hline TU & 27 & 0.74 & 0.59 & 9.75 & $0 / 2 / 0 / 0$ & 0.21 & 0.16 & 0.37 \\
\hline SE & 26 & 0.82 & 0.78 & 8.75 & $0 / 0 / 0 / 0$ & 0.05 & 0.24 & 0.46 \\
\hline SM & 27 & 0.78 & 0.49 & 7.25 & $0 / 0 / 0 / 0$ & 0.38 & 0.42 & 0.59 \\
\hline SS & 27 & 0.81 & 0.60 & 10.00 & $0 / 0 / 0 / 0$ & 0.26 & 0.03 & 0.11 \\
\hline GI & 24 & 0.70 & 0.72 & 8.50 & $3 / 2 / 3 / 0$ & -0.03 & 0.01 & 0.05 \\
\hline ET & 22 & 0.75 & 0.64 & 15.75 & $0 / 1 / 9 / 0$ & 0.15 & 0.07 & 0.21 \\
\hline PA & 22 & 0.75 & 0.69 & 13.00 & $1 / 0 / 6 / 0$ & 0.09 & 0.01 & 0.03 \\
\hline GR & 30 & 0.87 & 0.67 & 13.25 & $0 / 0 / 0 / 0$ & 0.24 & 0.05 & 0.17 \\
\hline RO & 23 & 0.86 & 0.74 & 10.50 & $0 / 0 / 0 / 0$ & 0.14 & 0.27 & 0.49 \\
\hline UK & 20 & 0.86 & 0.72 & 9.00 & $0 / 1 / 1 / 0$ & 0.16 & 1.06 & 0.77 \\
\hline BK & 6 & 0.85 & 0.88 & 5.75 & $0 / 0 / 0 / 0$ & -0.03 & 0.09 & 0.25 \\
\hline Average & 25 & 0.74 & 0.65 & 9.10 & & & & \\
\hline
\end{tabular}

ples from Sicily. A microscale Wahlund effect may arise from fine-grained genetic patchiness. It has been observed in molluscs with direct development, like Gemma gemma (Casu et al. 2005), but also in molluscs with a planktonic larval stage, like Siphonaria jeanae (Johnson \& Black 1984), Austrcochlea constricta (Parsons 1996) and Spisula ovalis (David et al. 1997). In species with a planktonic larval stage, the localised recruitment provoking isolation over short distances may be associated with limited water movement. Pearson (2003) inferred high levels of inbreeding to occur in lagoon populations of Cerastoderma glaucum and contemplated reduction of local dispersal opportunities as their cause.

\section{Genetic patterns of Cerastoderma glaucum in southern areas}

Cerastoderma glaucum is thought to have originated from the common ancestor with its closest living relative $C$. edule (Linné 1758) during the Messinian salinity crisis (late Miocene-early 

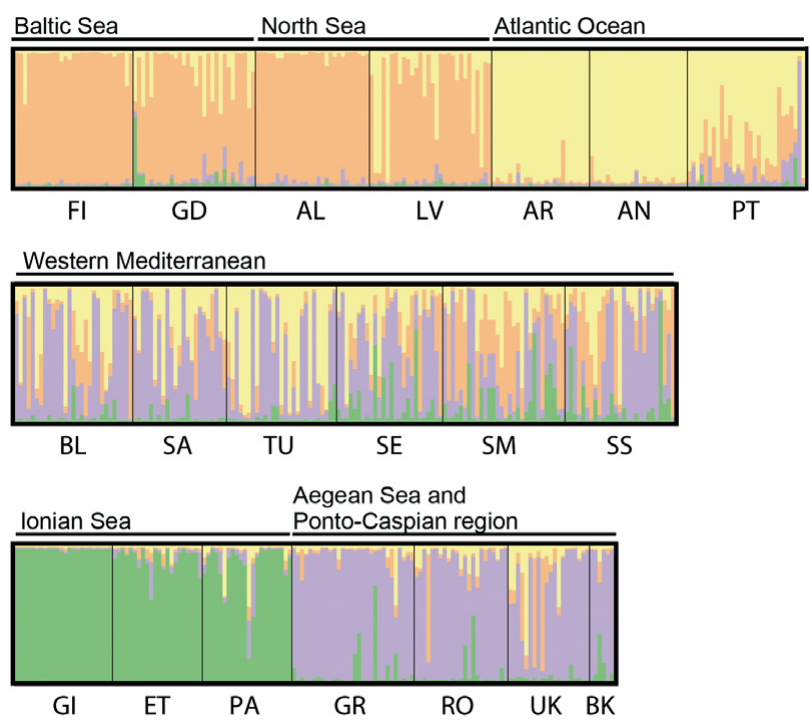

Fig. 4. Cerastoderma glaucum. Assignment of individuals to the 4 panmictic units inferred by Bayesian analysis in STRUCTURE. Each individual is represented by a vertical column that is partitioned into coloured segments that represent that individual's estimated membership fraction in each of the inferred units. See Table 3 for site definitions

Pliocene, around 5.5 million years ago [mya]) in the Mediterranean Sea (CIESM 2008).

Fossil records from Libya and Tunisia show that bivalves morphologically indistinguishable from modern Cerastoderma glaucum thrived in lagoons in the region of the present Mediterranean Sea in the early
Pliocene (Gaillard \& Testud 1980). Indeed, Tunisian and Ionian Sea samples had private haplogroups which contained highly divergent haplotypes and indicate a long and stable population history through Pleistocene glaciations. Terrestrial glacial refugia have been located in the Balkan Peninsula (reviewed in Hewitt 2000) and in the region of Tunisia (Magri et al. 2007). According to our results, the coastal regions of those areas are likely to have been glacial refugia for lagoonal marine species.

We found deep subdivisions in the genetic structure revealed by mtDNA (most of the $F_{\mathrm{ST}}$ values exceeding 0.8). Marked preglacial phylogeographic structure found in other European marine species has been explained by allopatric divergence in disjunct glacial refugia (e.g. Luttikhuizen et al. 2003, Papadopoulos et al. 2005). The level of divergence among Cerastoderma glaucum populations was higher than in other lagoon species (e.g. Astolfi et al. 2005) or in bivalves with a planktonic larval stage, even those with a fairly strong genetic structuring (e.g. Reeb \& Avise 1990, Arnaud et al. 2000, Lind et al. 2007). It was similar to the level of divergence often encountered within cryptic species complexes (e.g. Boissin et al. 2008).

The major break revealed in mtDNA suggests a long period of isolation between populations that gave rise to the 2 main phylogroups (cf. Nikula \& Väinölä 2003). Based on a divergence rate of $5 \%$ per million years, estimated by Nikula \& Väinölä (2003) from the divergence between Cerastoderma glaucum and C. edule that they assumed to date to the Atlantic-Mediter-

Table 3. Cerastoderma glaucum. Abbreviations and geographic coordinates of sampling sites and genetic diversity of population samples in the mitochondrial cytochrome c oxidase subunit I (COI) gene. Microsatellite samples from population ST (Sicily, Italy) were analysed as 3 separate samples (SE: Ettore; SM: Stagnone de Marsala; SS: Infersa). N: number of individuals; $\mathrm{N}_{\mathrm{H}}$ : number of haplotypes; $S$ : number of polymorphic sites; $H_{\mathrm{D}}$ : haplotype diversity; $\pi$ : nucleotide diversity

\begin{tabular}{|c|c|c|c|c|c|c|c|}
\hline Site code & Geographical location & Geographic coordinates & $\mathrm{N}$ & $\mathrm{N}_{\mathrm{H}}$ & $S$ & $H_{\mathrm{D}}$ & $\pi\left(\times 10^{2}\right)$ \\
\hline FI & Tvärminne, Finland & $59^{\circ} 50^{\prime} \mathrm{N}, 23^{\circ} 15^{\prime} \mathrm{E}$ & 24 & 4 & 3 & 0.431 & 0.092 \\
\hline GD & Gulf of Gdańsk, Poland & $54^{\circ} 40^{\prime} \mathrm{N}, 18^{\circ} 30^{\prime} \mathrm{E}$ & 18 & 3 & 2 & 0.307 & 0.062 \\
\hline $\mathrm{AL}$ & Sylt, Germany & $55^{\circ} 02^{\prime} \mathrm{N}, 8^{\circ} 24^{\prime} \mathrm{E}$ & 19 & 3 & 2 & 0.690 & 0.180 \\
\hline LV & Lake Veere, Netherlands & $51^{\circ} 35^{\prime} \mathrm{N}, 3^{\circ} 38^{\prime} \mathrm{E}$ & 19 & 3 & 9 & 0.205 & 0.184 \\
\hline AR & Arcachon, site 1, France & $44^{\circ} 41^{\prime} \mathrm{N}, 1^{\circ} 03^{\prime} \mathrm{W}$ & 16 & 7 & 6 & 0.625 & 0.169 \\
\hline AN & Arcachon, site 2, France & $44^{\circ} 41^{\prime} \mathrm{N}, 1^{\circ} 03^{\prime} \mathrm{W}$ & 16 & 5 & 4 & 0.450 & 0.097 \\
\hline PT & Ria Formosa, Portugal & $37^{\circ} 00^{\prime} \mathrm{N}, 7^{\circ} 58^{\prime} \mathrm{W}$ & 22 & 6 & 7 & 0.411 & 0.124 \\
\hline $\mathrm{BL}$ & Berre Lagoon, France & $43^{\circ} 24^{\prime} \mathrm{N}, 5^{\circ} 08^{\prime} \mathrm{E}$ & 21 & 11 & 19 & 0.814 & 0.565 \\
\hline SA & Cabras, Sardinia, Italy & $39^{\circ} 56^{\prime} \mathrm{N}, 8^{\circ} 31^{\prime} \mathrm{E}$ & 21 & 10 & 10 & 0.776 & 0.339 \\
\hline TU & Tunis Bay, Tunisia & $36^{\circ} 47^{\prime} \mathrm{N}, 10^{\circ} 17^{\prime} \mathrm{E}$ & 25 & 10 & 15 & 0.860 & 0.724 \\
\hline ST & Sicily, Italy & $37^{\circ} 47^{\prime} \mathrm{N}, 12^{\circ} 26^{\prime} \mathrm{E}$ & 17 & 6 & 5 & 0.772 & 0.212 \\
\hline GI & Gialova Lagoon, Greece & $36^{\circ} 57^{\prime} \mathrm{N}, 21^{\circ} 40^{\prime} \mathrm{E}$ & 11 & 4 & 8 & 0.600 & 0.446 \\
\hline ET & Etolikon, Greece & $38^{\circ} 28^{\prime} \mathrm{N}, 21^{\circ} 18^{\prime} \mathrm{E}$ & 10 & 7 & 15 & 0.911 & 0.973 \\
\hline PA & Papas Lagoon, Greece & $38^{\circ} 12^{\prime} \mathrm{N}, 21^{\circ} 22^{\prime} \mathrm{E}$ & 11 & 6 & 15 & 0.727 & 0.877 \\
\hline GR & Porto Lagos, Greece & $40^{\circ} 59^{\prime} \mathrm{N}, 25^{\circ} 09^{\prime} \mathrm{E}$ & 15 & 7 & 7 & 0.724 & 0.226 \\
\hline $\mathrm{RO}$ & Constanta, Romania & $44^{\circ} 11^{\prime} \mathrm{N}, 28^{\circ} 39^{\prime} \mathrm{E}$ & 20 & 5 & 5 & 0.721 & 0.232 \\
\hline UK & Seihierovka, Ukraine & $46^{\circ} 01^{\prime} \mathrm{N}, 30^{\circ} 24^{\prime} \mathrm{E}$ & 21 & 7 & 6 & 0.667 & 0.204 \\
\hline BK & Baku, Azerbaijan & $40^{\circ} 22^{\prime} \mathrm{N}, 49^{\circ} 53^{\prime} \mathrm{E}$ & 5 & 3 & 3 & 0.700 & 0.233 \\
\hline Average & & & 17 & 6 & 8 & 0.633 & 0.330 \\
\hline Total & & & 311 & 90 & 92 & & \\
\hline
\end{tabular}


ranean isolation 5.6 mya, we estimated that the eastern and western lineages diverged about 1.3 mya. The connection between the Aegean and Black Seas was established at the end of the Pliocene about 1.8 mya (Bacescu 1985). This would be the period when Mediterranean fauna, including $C$. glaucum, might have started to colonize the Black Sea. Long-term geological isolation of a cockle population in the Black Sea since the Pleistocene could explain the break, but is problematic, as marine taxa are believed to have gone extinct in the Black Sea during a severe salinity drop during the last glacial period (Peijnenburg et al. 2004). However, Nikula \& Väinölä (2003) pointed out that the lowest salinities measured for the late Pleistocene Black Sea were at a level that is well tolerated by C. glaucum in the present day Northern Baltic Sea. Therefore, the species' uninterrupted history in the Black Sea could plausibly date back even to the Early Pleistocene.

Then again, abrupt genetic breaks around Greece, similar to those in Cerastoderma glaucum, have been found in many non-lagoonal marine species that could not have persisted in the low salinity Black Sea of the last glacial period. They have been attributed to climatic and hydrological conditions in the Pleistocene and to the modern hydrological features of the eastern Mediterranean that have hindered genetic exchange between populations (see Domingues et al. 2005 and references therein).

The high level of divergence between the 2 main Cerastoderma glaucum mtDNA lineages accompanied by clear differentation at microsatellite loci lead us to support the view presented by Nikula \& Väinölä (2003) that the eastern and western evolutionary units of the lagoon cockle deserve a species or a subspecies status. The cockles sampled in the Ponto-Caspian region do not exhibit the morphological traits of the species reported previously in this region, C. umbonatum (= C. isthmicum) (Starobogatov 1994), so probably a new taxon name should be proposed. However, as no justification compatible with evolutionary theory allows defining a genetic divergence threshold for species delimitation, we are unable to judge based on the present data if the eastern versus western lagoon cockles deserve a species or a subspecies status. We also note that occasionally, as in the case of the Ionian Sea populations, such a strictly dichotomous taxonomy would be impossible to apply.

A major geographic break revealed by microsatellite data singled out the Ionian Sea populations. Positive selection inferred for the locus Cg11 in the Ionian Sea suggests that selective pressures have contributed to the differentiation of those populations from the nearby Ponto-Caspian type populations. However, the test aimed at detecting selection is more powerful when it is performed on a higher number of loci (Beaumont \& Nichols 1996). Pairwise $F_{\mathrm{ST}}$ values calculated without Cg11 showed that the nuclear genetic composition of the Ionian Sea populations closely resembled that of the more eastern (Ponto-Caspian) populations. This affinity has been found at many allozyme loci as well, but allozymes also yielded a locus similarly deviant to $C g 11$ (Nikula \& Väinölä 2003). The eastern character of the Ionian Sea nuclear genes was contradicted by the mtDNA data, as the Ionian Sea haplogroup belonged to the western phylogenetic lineage. The present study thus confirms the mixed cytonuclear character of Ionian Sea Cerastoderma glaucum, first observed with allozyme markers (Nikula \& Väinölä 2003).

\section{Genetic structure in post-glacially recolonized European marine regions}

Elaborating a scenario of post-glacial colonization of the northern parts of the distribution area of Cerastoderma glaucum and constructing hypotheses of glacial refugia for this species is not straightforward, since the geographic structures revealed by mtDNA and the 4 microsatellite loci are not congruent. Firstly, we will base the colonization scenario on mitochondrial DNA that is a maternally inherited, non-recombining molecule (Wolstenholme 1992). Then we will consider potential factors that may explain discrepancies between markers.

The lower intrapopulation diversity of Cerastoderma glaucum in northern compared to southern regions for mtDNA suggest that northern populations have experienced severe genetic drift due to bottlenecking and/ or founder events (Hewitt 1999). Significant results of neutrality tests for 1 North Sea (LV) and 3 Atlantic populations (AR, AN and PT) imply a history of fast population growth. This inference is supported by microsatellite data, where populations from post-glacially colonized areas in northern Europe were more divergent from each other than the southern, presumably older populations (Fig. 3b,c). Strong interpopulation differentiation due to founder effect and genetic drift has been also reported for northern European terrestrial animal populations that were post-glacially established (e.g. Johansson et al. 2006).

In the mtDNA structure, 2 geographic discontinuities were detected in Haplogroups I and II. The southern populations belonging to those haplogroups (SA and PT) probably survived throughout the Pleistocene glaciations and served as source populations for postglacial (re)colonization of the northern European coasts.

Dispersal by means of pelagic larval phase does not seem very probable among isolated lagoons. In the case of Cerastoderma glaucum, migrating birds seem a 
plausible vector for gene flow between disjunct areas. Lagoons like Ria Formosa (PT) often serve as bird feeding and resting areas during migration. Some waders (Charadriiformes) that undergo particularly long migratory flights use the East Atlantic Flyway, which is a major route for long-distance transport between the Iberian Peninsula and the Baltic Sea (Sánchez et al. 2006), which could explain the pattern observed in Haplogroup I. Birds have also been considered the means of migration of C. glaucum around the British Isles (Boyden \& Russell 1972) and from the Black Sea to the Caspian Sea (Nikula 2008). C. glaucum may well survive long-distance transport as it endures the loss of $22 \%$ of water from tissues and, during aerial exposure, its $\mathrm{LT}_{50}$ (lethal time for $50 \%$ of the individuals) is $220 \mathrm{~h}$ at $10^{\circ} \mathrm{C}$ (Boyden 1972). Live C. edule, a species closely resembling C. glaucum morphologically and ecologically, have been found attached to birds' feet (Green \& Figuerola 2005). Bird-mediated dispersal and colonization have not been often addressed in the marine phylogeographic studies (but see Muñoz et al. 2008), and are only beginning to be appreciated for freshwater organisms (De Gelas \& De Meester 2005, Figuerola et al. 2005).

\section{Discrepancies between microsatellite and mtDNA characteristics of populations}

The mitochondrial DNA structure of Cerastoderma glaucum exhibits much more abrupt geographic breaks than the structure at the microsatellite loci. At several locations populations do not display the mitochondrial lineage of the population with which they have the closest affinity according to microsatellite data.

Previous studies that looked at another type of nuclear genetic polymorphism, allozymes, also revealed from moderate to high levels of genetic structuring among Cerastoderma glaucum populations, but no geographic disjunctions resembling those we report for mtDNA Haplogroups I and II. Based on a study of 7 allozyme loci and 1 Mediterranean sample population along with 8 Atlantic, North Sea and Baltic Sea populations, Hummel et al. (1994) suggested that the populations from the Mediterranean Sea represent a different subspecies (C. g. glaucum) than those from the Atlantic (C. g. lamarcki). Mariani et al. (2002) studied 20 populations from the Mediterranean Sea and 1 from the Baltic Sea at 16 allozyme loci and found the widescale spatial structuring fit a stepping-stone model, with gene flow inversely related to geographic distance. At a smaller geographical scale, they did not find that genetic similarity was affected by geographic distance. In Nikula \& Väinölä (2003), 16 allozyme loci were studied in 7 European populations that covered the whole distribution range of C. glaucum from the Caspian Sea to the Baltic Sea. The population samples clustered according to the major geographical regions, revealing a major break largely corresponding to the main east-west division in mtDNA. The distinctive genetic characteristic of the Ionian Sea cockles was also noted. Thus, while conflicting with the geographic patterns found in mtDNA, our microsatellite data generally conform to the previously published nuclear (allozyme) data.

Nuclear and cytoplasmic markers have revealed different or conflicting patterns in many studies on marine organisms (e.g. Arnaud-Haond et al. 2003, Lemaire et al. 2005). The discrepancy in the strength of the patterns might be due to the fact that genetic drift is in general stronger on organellar than nuclear genomes (Ballard \& Whitlock 2004). In the present study, the patterns were also qualitatively different among genomes, thus further explanations are required. Firstly, selective sweeps have been shown to affect the nonrecombining mitochondrial genome more readily than the nuclear genome (Ballard \& Whitlock 2004, Bazin et al. 2006). Moreover, even in the absence of selection, introgression is more efficient in organelle genes compared to nuclear genes (Currat et al. 2008). Introgression events may have occurred repeatedly in Cerastoderma glaucum populations at the stage of their initial establishment, and could have entailed differential introgression of nuclear and mitochondrial genomes. A clear-cut separation of mitochondrial lineages even among geographically close populations which appear relatively similar in their nuclear genetic composition may be the result of high historical mtDNA polymorphism that has undergone differential lineage sorting (stochastic loss of lineages) in populations isolated relatively recently (so that nuclear gene pools did not have time to differentiate) (Avise et al. 1987). However, it seems unlikely that C. glaucum ever had the large continuous (panmictic) populations along the European coasts required to make this explanation credible.

In some bivalves, unbalanced sex ratio or sex-biased reproductive success has been invoked to explain the differences in the strength of mitochondrial and nuclear genetic patterns (Arnaud-Haond et al. 2003, Diaz-Almela et al. 2004). Gender-biased effective dispersal might also explain a geographically discontinuous mitochondrial genetic structure associated with a geographically continuous nuclear genetic structure. A scenario in which rare long-distance dispersal affects both sexes, while regular shorter-distance gene flow affects only males, would explain our observations, since after a genetic discontinuity is established in both genomes, recurrent male gene flow homogenizes, and 
thus erases, this discontinuity in the nuclear but not in the mitochondrial genome. Alternatively, if longdistance dispersal affects only females, it may also create a more discontinuous pattern in the mitochondrial relative to the nuclear genome. In Cerastoderma glaucum, gender-biased dispersal could hypothetically be driven by gender differences in survival during aerial exposure and starvation involved with passive dispersal mechanisms (e.g. transport by migrating birds or human activity).

In conclusion, the population genetic structuring we found in the lagoon cockle demonstrates that dispersal patterns of lagoon species with planktonic larvae may differ considerably from species living in open marine habitats. In particular, colonization events of new lagoon habitats potentially mediated by migrating birds may lead to striking geographic discontinuities in geographic genetic structures of lagoon species. Moreover, lagoon populations seem prone to loss of genetic diversity due to genetic drift and local selection, but on the other hand, these processes can lead to genetic differentiation between populations inhabiting different lagoons and thus promote the overall genetic diversity of lagoon species.

Acknowledgements. We are very grateful to A. D. Rogers for providing us with microsatellite primer sequences. We thank all those who helped us with sample collection: E. Egea, H. Hummel, J. Jansen, B. Kelemen, T. Kevrekidis, T. Kontula, M. Krakau, R. Lasota, M. Machado, A. E. Mogias, G. Sara, T. Sjölund, R. Sussarellu, R. Väinölä, J. Zaouali and staff at the University of Patras. We acknowledge E. Egea and A. Green for helpful comments and D. Rush for English correction. This publication is a part of the French-Polish PhD work of K.T. This work was partly supported by the GBIRM project (MARBEF Network of Excellence contract no. GOCE-CT-2003505446).

\section{LITERATURE CITED}

Antao T, Lopes A, Lopes RJ, Beja-Pereira A, Luikart G (2008) LOSITAN: a workbench to detect molecular adaptation based on a $F_{\mathrm{ST}}$-outlier method. BMC Bioinformatics 9:323, doi:10.1186/1471-2105-9-323

Arnaud S, Monteforte M, Galtier N, Bonhomme F, Blanc F (2000) Population structure and genetic variability of pearl oyster Pinctada mazatlanica along Pacific coasts from Mexico to Panama. Conserv Genet 1:299-307

Arnaud-Haond S, Monteforte M, Blanc F, Bonhomme F (2003) Evidence for male-biased effective sex ratio and recent step-by-step colonization in the bivalve Pinctada mazatlanica. J Evol Biol 16:790-796

Astolfi L, Dupanloup I, Rossi R, Bisol PM, Faure E, Congiu L (2005) Mitochondrial variability of sand smelt Atherina boyeri populations from north Mediterranean coastal lagoons. Mar Ecol Prog Ser 297:233-243

Avise JC, Arnold J, Ball RM, Bermingham E and others (1987) Intraspecific phylogeography: the mitochondrial DNA bridge between population genetics and systematics. Annu Rev Ecol Syst 18:489-522
Bacescu M (1985) The effects of geological and physicochemical factors on the distribution of marine plants and animals in the Mediterranean. In: Moraitou-Apostolopoulou M, Kiortsis V (eds) Mediterranean marine ecosystems. Plenum Press, New York, NY, p 195-212

Ballard JWO, Whitlock MC (2004) The incomplete natural history of mitochondria. Mol Ecol 13:729-744

Bandelt HJ, Forster P, Rohl A (1999) Median-joining networks for inferring intraspecific phylogenies. Mol Biol Evol 16: $37-48$

Barnes RSK (1980) Coastal lagoons. Cambridge University Press, Cambridge

Barnes RSK (1988) The faunas of land locked lagoons: chance differences and the problems of dispersal. Estuar Coast Shelf Sci 26:309-318

$>$ Bazin E, Glémin S, Galtier N (2006) Population size does not influence mitochondrial genetic diversity in animals. Science 312:570-572

Beaumont MA, Nichols RA (1996) Evaluating loci for use in the genetic analysis of population structure. Proc Biol Sci 263:1619-1626

Belkhir K, Borsa P, Goudet J, Chikhi L, Bonhomme F (1998) Genetix, logiciel sous Windows ${ }^{\mathrm{TM}}$ pour la génétique des populations. Laboratoire Génome et Populations, CNRS UPR 9060, Université de Montpellier II, Montpellier

Benjamini Y, Hochberg Y (1995) Controlling the false discovery rate: a practical and powerful approach to multiple testing. J R Stat Soc B 57:289-300

> Boissin E, Féral JP, Chenuil A (2008) Defining reproductively isolated units in a cryptic and syntopic species complex using mitochondrial and nuclear markers: the brooding brittle star, Amphipholis squamata (Ophiuroidea). Mol Ecol 17:1732-1744

Boyden CR (1972) The behaviour, survival and respiration of the cockles Cerastoderma edule and C. glaucum in air. J Mar Biol Assoc UK 52:661-680

Boyden CR, Russell PJC (1972) The distribution and habitat range of brackish water cockle (Cardium (Cerastoderma) glaucum) in the British Isles. J Anim Ecol 41:719-734

Brock V (1979) Habitat selection of two congeneric bivalves, Cardium edule and C. glaucum in sympatric and allopatric populations. Mar Biol 54:149-156

> Castric V, Bernatchez L, Belkhir K, Bonhomme F (2002) Heterozygote deficiencies in small lacustrine populations of brook charr Salvelinus fontinalis Mitchill (Pisces, Salmonidae): a test of alternative hypotheses. Heredity 89: $27-35$

Casu M, Maltagliati F, Cossu P, Lai T, Galletti MC, Castelli A, Commito JA (2005) Fine-grained spatial genetic structure in the bivalve Gemma gemma from Maine and Virginia (USA), as revealed by Inter-Simple Sequence Repeat markers. J Exp Mar Biol Ecol 325:46-54

CIESM (The Mediterranean Science Commission) (2008) The Messinian Crisis from mega-deposits to microbiology: a consensus report. In: Briand F (ed) CIESM Workshop Monographs 33. CIESM, Monaco

Currat M, Ruedi M, Petit RJ, Excoffier L (2008) The hidden side of invasions: massive introgression by local genes. Evolution 62:1908-1920

David P, Perdieu MA, Pernot AF, Jarne P (1997) Fine-grained spatial and temporal population genetic structure in the marine bivalve Spisula ovalis. Evolution 51:1318-1322

> David P, Pujol B, Viard F, Castella V, Goudet J (2007) Reliable selfing rate estimates from imperfect population genetic data. Mol Ecol 16:2474-2487

Dawson AG (1992) Ice age earth: late Quaternary geology and climate. Routledge, London 
De Gelas K, De Meester L (2005) Phylogeography of Daphnia magna in Europe. Mol Ecol 14:753-764

Diaz-Almela E, Boudry P, Launey S, Bonhomme F, Lapegue S (2004) Reduced female gene flow in the European flat oyster Ostrea edulis. J Hered 95:510-516

> Domingues VS, Bucciarelli G, Almada VC, Bernardi G (2005) Historical colonization and demography of the Mediterranean damselfish, Chromis chromis. Mol Ecol 14: 4051-4063

Evanno G, Regnaut S, Goudet J (2005) Detecting the number of clusters of individuals using the software structure: a simulation study. Mol Ecol 14:2611-2620

Excoffier L, Laval G, Schneider S (2005) Arlequin ver. 3.0: an integrated software package for population genetics data analysis. Evol Bioinform Online 1:47-50

Figuerola J, Green A, Michot T (2005) Invertebrate eggs can fly: evidence of waterfowl-mediated gene flow in aquatic invertebrates. Am Nat 165:274-280

Folmer O, Black M, Hoeh W, Lutz RA, Vrijenhoek R (1994) DNA primers for amplification of mitochondrial cytochrome c oxidase subunit I from diverse metazoan invertebrates. Mol Mar Biol Biotechnol 3:294-299

> Fu YX, Li WH (1993) Statistical tests of neutrality of mutations. Genetics 133:693-709

Gaillard JM, Testud AM (1980) Comparative study of Quaternary and present-day lagoon populations of Cardium glaucum (syn. Cerastoderma glaucum) Bruguière, Mollusca, Bivalvia. In: Salem MJ, Busrewil MT (eds) The geology of Libya, Vol 3. Academic Press, London, p 809-813

$>$ Green A, Figuerola J (2005) Recent advances in the study of long-distance dispersal of aquatic invertebrates via birds. Divers Distr 11:149-156

Hall TA (1999) BioEdit: a user-friendly biological sequence alignment editor and analysis program for Windows 95/ 98/NT. Nucleic Acids Symp Ser 41:95-98

> Hewitt GM (1999) Post-glacial recolonization of European biota. Biol J Linn Soc 68:87-112

> Hewitt GM (2000) The genetic legacy of the Quaternary ice ages. Nature 405:907-913

Hummel H, Wołowicz M, Bogaards RH (1994) Genetic variability and relationships for populations of Cerastoderma edule and of the C. glaucum complex. Neth J Sea Res 33:81-89

Jakobsson M, Rosenberg NA (2007) CLUMPP: a cluster matching and permutation program for dealing with label switching and multimodality in analysis of population structure. Bioinformatics 23:1801-1806

> Johansson M, Primmer CR, Merilä J (2006) History vs. current demography: explaining the genetic population structure of the common frog (Rana temporaria). Mol Ecol 15: 975-983

Johnson MS, Black R (1984) Pattern beneath the chaos: the effect of recruitment on genetic patchiness in an intertidal limpet. Evolution 38:1371-1383

Lemaire C, Versini JJ, Bonhomme F (2005) Maintenance of genetic differentiation across a transition zone in the sea: discordance between nuclear and cytoplasmic markers. J Evol Biol 18:70-80

Lewontin RC, Krakauer J (1973) Distribution of gene frequency as a test of the theory of the selective neutrality of polymorphisms. Genetics 74:175-195

Lind CE, Evans BS, Taylor JJU, Jerry DR (2007) Population genetics of a marine bivalve, Pinctada maxima, throughout the Indo-Australian Archipelago shows differentiation and decreased diversity at range limits. Mol Ecol 16: 5193-5203

> Luttikhuizen PC, Drent J, Baker AJ (2003) Disjunct distribution of highly diverged mitochondrial lineage clade and population subdivision in a marine bivalve with pelagic larval dispersal. Mol Ecol 12:2215-2229

Lynch M (1984) Destabilizing hybridization, general purpose genotypes and geographic parthenogenesis. Q Rev Biol 59:257-290

Maggs CA, Castilho R, Foltz DW, Henzler C and others (2008) Evaluating signatures of glacial refugia for North Atlantic benthic marine taxa. Ecology 89:S108-S122

> Magri D, Fineschi S, Bellarosa R, Buonamici A, Sebastiani F, Schirone B, Simeone MC, Vendramin GG (2007) The distribution of Quercus suber chloroplast haplotypes matches the palaeogeographical history of the western Mediterranean. Mol Ecol 16:5259-5266

> Mariani S, Ketmaier V, De Matthaeis E (2002) Genetic structuring and gene flow in Cerastoderma glaucum (Bivalvia: Cardiidae): evidence from allozyme variation at different geographic scales. Mar Biol 140:687-697

Mason CF (1986) Invertebrate populations and biomass over four years in a coastal, saline lagoon. Hydrobiologia 133: $21-29$

> Muñoz J, Gómez A, Green A, Figuerola J, Amat F, Rico C (2008) Phylogeography and local endemism of the native Mediterranean brine shrimp Artemia salina (Branchiopoda: Anostraca). Mol Ecol 17:3160-3177

> Nei M (1978) Estimation of average heterozygosity and a genetic distance from a small number of individuals. Genetics 89:583-590

Nei M (1987) Molecular evolutionary genetics. Columbia University Press, New York, NY

Nikula R (2008) Phylogeography and hybrid swarms: history of brackish water bivalve diversity in North European marginal seas. PhD thesis, University of Helsinki

Nikula R, Väinölä R (2003) Phylogeography of Cerastoderma glaucum (Bivalvia: Cardiidae) across Europe: a major break in the Eastern Mediterranean. Mar Biol 143: 339-350

> Pannacciulli FG, Bishop JDD, Hawkins SJ (1997) Genetic structure of populations of two species of Chthamalus (Crustacea: Cirripedia) in the north-east Atlantic and Mediterranean. Mar Biol 128:73-82

> Papadopoulos LN, Peijnenburg KTCA, Luttikhuizen PC (2005) Phylogeography of the calanoid copepods Calanus helgolandicus and C. euxinus suggests Pleistocene divergences between Atlantic, Mediterranean, and Black Sea populations. Mar Biol 147:1353-1365

> Parsons KE (1996) The genetic effects of larval dispersal depend on spatial scale and habitat characteristics. Mar Biol 126:403-414

Patarnello T, Volckaert FA, Castilho R (2007) Pillars of Hercules: Is the Atlantic-Mediterranean transition a phylogeographical break? Mol Ecol 16:4426-4444

Pearson C (2003) The genetic population structure of the lagoon specialists Nematostella vectensis, Cerastoderma glaucum and Gammarus insensibilis from populations along the southern and eastern coasts of the United Kingdom. PhD thesis, University of Southampton

> Peijnenburg KTCA, Breeuwer JAJ, Pierrot-Bults AC, Menken SBJ (2004) Phylogeography of the planktonic chaetognath Sagitta setosa reveals isolation in European seas. Evolution 58:1472-1487

> Pritchard JK, Stephens M, Donnelly P (2000) Inference of population structure using multilocus genotype data. Genetics 155:945-959

> Reeb CA, Avise JC (1990) A genetic discontinuity in a continuously distributed species: mitochondrial DNA in the American oyster, Crassostrea virginica. Genetics 124: $397-406$ 
Rosenberg NA (2004) Distruct: a program for the graphical display of population structure. Mol Ecol Notes 4: 137-138

Rozas J, Sánchez-DelBarrio JC, Messeguer X, Rozas R (2003) DnaSP, DNA polymorphism analyses by coalescent and other methods. Bioinformatics 19:2496-2497

Rygg B (1970) Studies on Cerastoderma edule (L.) and Cerastoderma glaucum (Poiret). Sarsia 43:65-80

Sánchez M, Green AJ, Castellanos EM (2006) Internal transport of seeds by migratory waders in the Odiel marshes, south-west Spain: consequences for long-distance dispersal. J Avian Biol 37:201-206

Starobogatov YI (1994) Fauna and zoogeography of molluscs of Turkmenistan. In: Fet V, Atamuradov KI (eds) Biogeography and ecology of Turkmenistan. Kluwer, Dordrecht, p 535-543

Editorial responsibility: Philippe Borsa, Montpellier, France
Tajima F (1989) Statistical method for testing the neutral mutation hypothesis by DNA polymorphism. Genetics 123:585-595

> Tamura K, Dudley J, Nei M, Kumar S (2007) MEGA4: Molecular Evolutionary Genetics Analysis (MEGA) software version 4.0. Mol Biol Evol 24:1596-1599

> Verhoeven KJF, Simonsen KL, McIntyre LM (2005) Implementing false discovery rate control: increasing your power. Oikos 108:643-647

Weir BS (1979) Inferences about linkage disequilibrium. Biometrics 35:235-254

Weir BS, Cockerham CC (1984) Estimating F-statistics for the analysis of population structure. Evolution 38:1358-1370

- Weir BS, Hill WG (2002) Estimating F-statistics. Annu Rev Genet 36:721-750

Wolstenholme DR (1992) Animal mitochondrial DNA: structure and evolution. Int Rev Cytol 141:173-216

Submitted: May 7, 2009; Accepted: February 18, 2010 Proofs received from author(s): April 28, 2010 